\title{
High Expression of C5L2 Correlates with High Proinflammatory Cytokine Expression in Advanced Human Atherosclerotic Plaques
}

\author{
Santosh Vijayan, ${ }^{\star \dagger}$ Yaw Asare, ${ }^{* \ddagger}$ Jochen Grommes, ${ }^{\S}$ Oliver Soehnlein, ${ }^{*}$ Esther Lutgens, ${ }^{\boldsymbol{\Phi} \|}$ Gansuvd Shagdarsuren, ${ }^{* *}$ \\ Ariunaa Togtokh, ${ }^{* *}$ Michael J. Jacobs, ${ }^{\ell \dagger \dagger}$ Jens W. Fischer, ${ }^{\dagger}$ Jürgen Bernhagen, ${ }^{\dagger,+*}$ Christian Weber, ${ }^{\Phi\|\|}$ Andreas Schober, ${ }^{* \Phi}$ and \\ Erdenechimeg Shagdarsuren*

\begin{abstract}
From the Institute for Molecular Cardiovascular Research, * the Institute of Biochemistry and Molecular Cell Biology, ${ }^{\ddagger}$ and the European Vascular Centre Aachen-Maastricht, ${ }^{\S}$ University Hospital, Aachen, Germany; the Institute for Pharmacology and Clinical Pharmacology, ${ }^{\dagger}$ Heinrich-Heine-Universität Düsseldorf, Düsseldorf, Germany; the Institute for Cardiovascular Prevention, "Ludwig-Maximilians-University Munich, Munich, Germany; the Department of Medical Biochemistry," Amsterdam Medical Center, University of Amsterdam, Amsterdam, The Netherlands; the Department of Nephrology, ** Health Sciences University of Mongolia, Ulaanbaatar, Mongolia; the European Vascular Center Aachen-Maastricht, ${ }^{\dagger \dagger}$ Maastricht University Medical Centre, Maastricht, The Netherlands; and the August-Lenz-Stiftung at Ludwig-Maximilians-University Hospital Munich, ${ }^{\ddagger}$ Munich, Germany
\end{abstract}

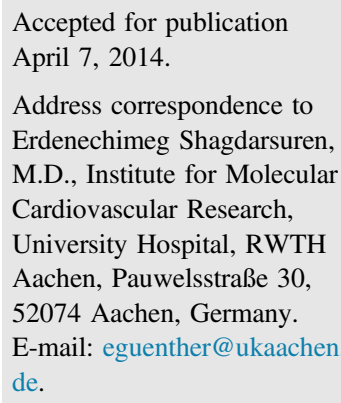

\begin{abstract}
The complement anaphylatoxin C5a functions through its two receptors, C5aR (CD88) and C5a receptorlike 2 (C5L2). Their role in atherosclerosis is incompletely understood. We, therefore, analyzed C5aR and probed the yet unknown expression and function of $\mathrm{C} 5 \mathrm{~L} 2$ in human atherogenesis. Human atherosclerotic plaques obtained by endarterectomy were staged and analyzed for C5L2 and C5aR by IHC and quantitative real-time PCR. C5L2-expressing cells in plaques were mostly macrophages, less neutrophils and endothelial cells, as determined by double immunostaining. Although early influx of $\mathrm{C} \mathrm{aR}^{+}$cells was detected, C5L2 levels increased with lesion complexity and colocalized with C5aR and oxidized lowdensity lipoprotein. Gene expression of $\mathrm{C} 5 \mathrm{~L} 2$ and $\mathrm{C} 5 \mathrm{aR}$ showed similar trends, such as the receptorexpressing cells. The expression of $\mathrm{C} 5 \mathrm{~L} 2$ in advanced lesions correlated with increased levels of IL-1 $\beta$ and tumor necrosis factor- $\alpha$ in plaques. Furthermore, in vitro experiments in macrophages from wildtype and C512- and C5ar-deficient mice corroborated the contributing role of C512 in oxidized lowdensity lipoprotein-pretreated C5a-induced cytokine expression, as measured by enzyme-linked immunosorbent assay. Finally, C5l2- and C5ar-deficient peripheral blood mononuclear cells showed less arrest on tumor necrosis factor- $\alpha$-stimulated mouse endothelial cells in vitro when compared with wild-type controls. Taken together, prominent C5L2 expression in advanced atherosclerotic stages directly correlates with high levels of proinflammatory cytokines. This might indicate a proinflammatory role of $\mathrm{C} 5 \mathrm{~L} 2$ in atherosclerosis that needs to be pursued in the future by applying in vivo mouse models. (Am J Pathol 2014, 184: 2123-2133; http://dx.doi.org/10.1016/j.ajpath.2014.04.004)
\end{abstract}

Atherosclerosis is a chronic inflammatory disease ${ }^{1,2}$ with involvement of both innate and adaptive immunity in its pathogenesis. $^{2}$ C5a, a potent soluble anaphylatoxin, is a multifunctional proinflammatory mediator, which promotes the recruitment and activation of neutrophils and monocytes. ${ }^{3} \mathrm{C} 5 \mathrm{a}$ interacts primarily with its two receptors, the classic proinflammatory $\mathrm{C} 5 \mathrm{a}$ receptor $(\mathrm{C} 5 \mathrm{aR} ; \mathrm{CD} 88)$ and relative newly identified C5a receptor-like 2 [C5L2; G Protein-Coupled Receptor (GPR) 77]. In addition to immune cells, C5aR has also been detected in endothelial cells (ECs), ${ }^{4}$ vascular smooth muscle cells (VSMCs), ${ }^{5}$ and different tissues, including heart. A proinflammatory role for $\mathrm{C} 5 \mathrm{aR}$ in many inflammatory diseases has been well demonstrated. ${ }^{7,8}$ We previously reported a strong protective effect by short-term blockade of C5aR on neointimal plaque formation.

Supported by Deutsche Forschungsgemeinschaft grants GU1223/3-1 (E.S.), SO876/3-1 (S.V.), BE1977/4-2 FOR809, and IRTG1508 (Y.A., J.B., and C.W.) and IZKF 112c (S.V.).

S.V. and Y.A. contributed equally to this work.

Disclosures: None declared. 
Such as C5aR, C5L2 is also expressed on both immune (neutrophils, macrophages, and immature dendritic cells) and nonimmune cells, such as epithelial cells, ${ }^{3}$ and in different tissues, such as adrenal gland, spleen, and heart. ${ }^{6}$ The pathophysiological role of C5L2 is both enigmatic and controversial. Unlike C5aR, C5L2 is incapable of binding to intracellular G proteins. However, C5L2 acts as a positive regulator, critical in maintaining $\mathrm{C} 5 \mathrm{a}$ and $\mathrm{C} 3 \mathrm{a}$ signaling by heterodimerizing with $\mathrm{C} 5 \mathrm{aR}$ or $\mathrm{C} 3 \mathrm{aR} .{ }^{9} \mathrm{C} 5 \mathrm{~L} 2$ functions as a recycling decoy receptor binding to free $\mathrm{C} 5 \mathrm{a}$ and regulating its extracellular bioactivity. ${ }^{10}$ This limited the proinflammatory effect of $\mathrm{C} 5 \mathrm{a}$ in an in vivo model of immune complex lung disease. ${ }^{11} \mathrm{C} 5 \mathrm{~L} 2$ can negatively regulate $\mathrm{C} 5 \mathrm{aR}$ and has a discrete signaling function. ${ }^{12,13} \mathrm{C} 5 \mathrm{~L} 2$ functions as an intracellular receptor and is activated only after binding of $\mathrm{C} 5 \mathrm{a}$ to $\mathrm{C} 5 \mathrm{aR} .{ }^{13} \mathrm{In}$ contrast, in a mouse model of moderate sepsis, $\mathrm{C} 512^{-/-}$mice exhibited an improved survival rate, similar to $\mathrm{C} 5 \mathrm{ar}^{-1-}$ mice, suggesting that C5L2 can exert a proinflammatory effect similar to C5aR. ${ }^{14}$ Taken together, these data indicate the complex and discrete role of $\mathrm{C} 5 \mathrm{~L} 2$ in different diseases.

Although C5L2 has been implicated in many inflammatory diseases, the expression and function of C5L2 in the vasculature, and the stage-dependent expression of both $\mathrm{C} 5 \mathrm{aR}$ and C5L2 receptors in atherosclerosis, are less known. A recent publication reported the mRNA expression of C5L2 and $\mathrm{C} 5 \mathrm{aR}$ in the aorta of apolipoprotein E-deficient $\left(\right.$ Apo $\left.^{-1-}\right)$ mice. Although C5aR increased in Apoe ${ }^{-1-}$ mice when compared with control wild-type (WT) mice, the reverse was seen for C5L2 expression. ${ }^{15}$ However, in a mouse model of neurodegeneration, varying levels of C5L2, depending on the stage of the disease, were observed, ${ }^{16}$ prompting us to hypothesize that a similar trend could be seen in atherosclerosis.

To test this hypothesis, we analyzed human carotid artery atherosclerotic plaques for $\mathrm{C} 5 \mathrm{aR}$ and $\mathrm{C} 5 \mathrm{~L} 2$. We revealed the presence of C5L2 in all pathological stages, and its high expression in advanced lesions directly correlates with high levels of proinflammatory cytokines in the plaques. The analysis of proinflammatory cytokines in bone marrowderived macrophages (BMDMs) from WT, $\mathrm{C} \mathrm{ar}^{-/-}$, and
$C 512^{-/-}$mice underlined the importance of the presence of both receptors for C5a-induced cytokine secretion and provided evidence for the contributory role of $\mathrm{C} 5 \mathrm{~L} 2$.

\section{Materials and Methods}

\section{Human Carotid Artery Samples}

Carotid artery specimens from autopsied individuals, which were found to be healthy artery $(n=9)$ and human carotid artery lesions from patients undergoing endarterectomy $(n=$ 98) were collected with patients' informed consent and approved by an institutional review committee following the Declaration of Helsinki. The plaques were staged 0 to VI ( $n=9$ to 20 per stage) in conformity with a modified American Heart Association classification system ${ }^{17,18}$ by two independent researchers (E.L. and E.S.). Plaques staged I through III were considered as early atherosclerotic lesions, and those staged IV through VI were considered as advanced pathological lesions (Table 1).

\section{RNA Extraction and cDNA Synthesis}

RNA was isolated from human carotid artery lesions from 50 patients undergoing endarterectomy ( $n=4$ to 9 per stage) using QIAzol lysis reagent (Qiagen, Hilden, Germany) and reverse transcribed using a high-capacity cDNA Reverse Transcription Kit (Applied Biosystems, Darmstadt, Germany). Normal human aortic mRNA (Clontech, Mountain View, CA) was used as a healthy control.

\section{Real-Time PCR}

Quantitative real-time PCR was performed using a Maxima SYBR Green/ROX qPCR Master Mix kit (Fermentas, St. Leon-Rot, Germany) in thermal cycler model 7900 HT (Applied Biosystems). Specific human $\mathrm{RT}^{2}$ qPCR Primer Assay (SA Biosciences, Hilden, Germany) for C5aR (CD88) and C5L2 (GPR77) and a reference gene, glyceraldehyde-3-phosphate dehydrogenase, were used.

Table 1 Classification of Human Atherosclerotic Plaques

\begin{tabular}{|c|c|c|}
\hline $\begin{array}{l}\text { Plaque } \\
\text { stages }\end{array}$ & $\begin{array}{l}\text { No. of } \\
\text { specimens }\end{array}$ & Characteristics by histological examination \\
\hline 0 & 9 & Normal human arteries \\
\hline I & 9 & Type I lesion, an intimal thickening with accumulation of SMCs only \\
\hline II & 14 & Type II lesion, an intimal xanthoma with luminal accumulation of foam cells without a fibrous cap and necrotic core \\
\hline III & 20 & $\begin{array}{l}\text { A pathological intimal thickening with intracellular and incompletely coalesced extracellular lipids and fibrous cap } \\
\text { formation, mild plaque inflammation without necrotic core }\end{array}$ \\
\hline V & 17 & $\begin{array}{l}\text { A fibrous cap atheroma with thick cellular caps overlying a largely necrotic and fatty core, calcification and } \\
\text { intraplaque hemorrhage, moderate plaque inflammation, patterns of multilayering }\end{array}$ \\
\hline VI & 18 & $\begin{array}{l}\text { A vulnerable thin fibrous cap atheroma with rupture, hemorrhage, and thrombi, moderate grade of inflammation } \\
\text { with infiltration, and rare SMCs with an underlying necrotic core }\end{array}$ \\
\hline
\end{tabular}




\section{Alkaline Phosphatase Staining on Human Lesions}

Paraffin-embedded sections were stained with primary antibodies for anti-human C5aR (CD88; Abnova, Heidelberg, Germany) and C5L2 (GPR77; GeneTex, Irvine, CA) or appropriate isotypes. Visualization was achieved by immunohistochemical (IHC) avidin-biotin- complex method with alkaline phosphatase enzyme development (Vector Laboratories, Burlington, ON, Canada). Frozen serial sections were used for colocalization staining with anti-malondialdehydeoxidized low-density lipoprotein (oxLDL) antibody (Abcam, Cambridge, UK) or the appropriate isotype antibody and counterstained with Mayer's Hämalaun.

\section{Double-Immunofluorescence Staining}

Primary antibody for C5L2 was costained in paraffinembedded sections with anti-smooth muscle $\alpha$-actin for VSMCs (Dako, Glostrup, Denmark), anti-CD68 macrophages and anti-CD31 for ECs (both from Santa Cruz Biotechnology, Santa Cruz, CA), anti-CD177 for neutrophils and anti-CD3 for $\mathrm{T}$ cells (both from AbD Serotec, Oxford, UK), or appropriate isotypes. Staining was detected by secondary anti-rabbit $\mathrm{Cy}-3$ or anti-mouse or anti-goat fluorescein isothiocyanate antibodies (all from Jackson ImmunoResearch, Suffolk, UK). Cell nuclei were counterstained with DAPI (Vector Laboratories). Images were visualized using a Leica DMLB microscope (Leica Microsystems, Wetzlar, Germany). Quantification levels of double-positive cells for $\mathrm{C} 5 \mathrm{~L} 2^{+} \mathrm{CD} 68^{+}, \mathrm{C} 5 \mathrm{~L} 2^{+} \mathrm{CD} 177^{+}$, and $\mathrm{C} 5 \mathrm{~L} 2{ }^{+} \mathrm{CD} 31^{+}$cells in five view fields were manually counted and calculated as percentages.

\section{ELISA for Cytokines}

IL-1 $\beta$, tumor necrosis factor (TNF)- $\alpha$, and IL-10 were measured using enzyme-linked immunosorbent assay (ELISA) kits (all from eBioscience, Frankfurt, Germany) in tissue extracts of human plaques and in cell culture supernatants of MM6 cells (human monocytic/macrophage cell line, $1 \times 10^{6} / \mathrm{mL}$ to $2 \times 10^{6} / \mathrm{mL}$ ). MM6 cells were stimulated with either $0.5 \mu \mathrm{g} / \mathrm{mL}$ human recombinant C5a (SigmaAldrich, Hamburg, Germany) for 4 hours or $30 \mu \mathrm{g} / \mathrm{mL}$ oxLDL (Calbiochem, Darmstadt, Germany) alone for 4 hours, or combined and pretreated (30 minutes) with $2.5 \mu \mathrm{g} /$ $\mathrm{mL}$ human C5aR antagonist (C5aRA), JPE-1375 (Jerini AG, Berlin, Germany), as indicated in figure legends.

\section{Mouse Macrophage Isolation, Differentiation, and Gene Silencing}

The BMDMs were isolated from $\mathrm{C}_{5 \mathrm{ar}}^{-1-}, \mathrm{C}^{2} \mathrm{2}^{-1-}$, and C57Bl/6 WT mice purchased from Jackson Laboratory (Bar Harbor, ME). Animal procedures were approved by local authorities and complied with the German animal protection law. Mice were euthanized by cervical dislocation. BM cell suspensions were obtained by flushing femurs, resuspended in
Dulbecco's modified Eagle's medium-F12 medium supplemented with $10 \%$ fetal calf serum and 15\% L929-conditioned medium, and cultured for 7 days to allow differentiation into primary macrophages. F4/80 (rat anti-mouse IgG2a-activated protein C; eBiosciences, Frankfurt, Germany) and CD11b (rat anti-mouse IgG2b PerCP-Cy5.5; BD Pharmingen, Heidelberg, Germany) expression was determined by flow cytometry (FACSCanto II; BD Biosciences, Heidelberg, Germany) to confirm the macrophage phenotype. BMDMs were then stimulated with $100 \mathrm{ng} / \mathrm{mL}$ mouse recombinant C5a (R\&D Systems, Wiesbaden, Germany) for 4 hours, $30 \mu \mathrm{g} / \mathrm{mL}$ oxLDL (Calbiochem) for 4 hours, and $2.5 \mu \mathrm{g} / \mathrm{mL}$ human C5aRA (JPE-1375; Jerini AG) for 30 minutes. Human C5aRA (JPE1375) potently inhibits human C5aR and has a higher activity on murine C5ar. ${ }^{5}$ The supernatants were collected for the measurement of IL- $1 \beta$, TNF- $\alpha$, and high-mobility group box 1 (HMGB1) protein (Mybiosource, San Diego, CA) by ELISA. Experiments were repeated three times and measured in duplicate in each experiment. To silence the gene expression for $C 512$ in BMDM, cells were transfected with ON-TARGET plus mouse Gpr77 (C5l2) siRNA-SMARTpool (L-05649200-0005) using DharmaFECT 4 transfection reagent (both from Thermo Scientific, Ulm, Deutschland). After 72 hours, cells were stimulated with C5a and oxLDL for 4 hours, and the supernatant was collected for the measurement of IL- $1 \beta$ and TNF- $\alpha$ release.

Isolation of Mouse Peripheral Blood Mononuclear Cells and Analysis of the Surface Expression of Integrins

Blood from the retro-orbital plexus was sampled from WT, $\mathrm{C} \mathrm{ar}^{-/-}$, and $\mathrm{C} 5 \mathrm{l}^{-/-}$mice. Peripheral blood mononuclear cells (PBMCs) were isolated by Ficoll gradient centrifugation method and suspended in HBSS containing $1 \mathrm{mmol} / \mathrm{L} \mathrm{CaCl}_{2}$ and $\mathrm{MgCl}_{2}$. Cells were either treated with $50 \mathrm{ng} / \mathrm{mL}$ phorbol myristate acetate (Sigma-Aldrich, Hamburg, Germany) for 15 minutes or left untreated, as indicated. Flow cytometric analysis using FACSCanto II (BD Biosciences) was performed and analyzed using FlowJo software version 7.6 (Tree Star, Ashland, OR) after anti-CD11b labeling and careful washing of cells.

\section{Laminar Flow Adhesion Assay}

Arrest of calcein-AM (Molecular Probes, Eugene, OR)labeled PBMCs from WT, $\mathrm{C}^{\mathrm{ar} r^{-/-}}$, and $\mathrm{C} 512^{-/-}$mice, on confluent small-vessel EC (SVEC) monolayers, pretreated with $20 \mathrm{ng} / \mathrm{mL}$ mouse TNF- $\alpha$, as indicated, was analyzed in parallel wall chambers under flow conditions ( 1.5 dynes/ $\mathrm{cm}^{2}, 5$ minutes). Adhesion was quantified with the help of ImageJ software version 1.39 (NIH, Bethesda, MD), as previously established. ${ }^{19}$

\section{Statistical Analysis}

All data are given as means \pm SEM, analyzed for normality by Kolmogorov-Smirnov test or D'Agostino and Pearson 
omnibus test. Then, data were analyzed as appropriate by either one-way analysis of variance with Tukey's multiplecomparison test or nonparametric Kruskal-Wallis test and Pearson $r$ correlation analysis (Prism 4.0 software; GraphPad Software, San Diego, CA). $P<0.05$ was considered to be statistically significant.

\section{Results}

\section{C5L2 Is Prominently Expressed in Different Stages of Human Atherosclerotic Plaques}

Human carotid artery atherosclerotic plaques were staged ( 0 to VI) by two independent experts (E.L. and S.E.) (Table 1). Information on the use of lipid management therapy and other medications, relevant life style, and diseases of patients (Supplemental Table S1 and Supplemental Table S2) was obtained to exclude their pleiotropic effect on the expression of $\mathrm{C} 5$ a receptors. We then determined, for the first time to our knowledge, the expression of two C5a receptors in different stages of human atherosclerotic plaques (Figure 1). The presence of C5L2-expressing cells and gene expression profile in the atherosclerotic plaque is shown in Figure 1, A and B. In the healthy artery (0) and stage I, staining for C5L2 was essentially negative. C5L2 increased over time from stage II through all pathological stages (III to VI) (Figure 1A). A marked increase in mRNA of C5L2 in atherosclerotic stages II to VI was observed when compared with their low levels in stages 0 and I (Figure 1B). Although only a few C5aR-positive cells were detected in stages 0 and $\mathrm{I}$, a sudden and significant increase in the content of $\mathrm{C}_{5} \mathrm{aR}^{+}$ cells at stage II of plaque development was observed (Figure 1C). Such as C5L2, the gene expression for C5aR markedly increased in stages II to VI (Figure 1D). More important, the sudden increase in the number of $\mathrm{C}_{5} \mathrm{aR}^{+}$cells in human atherosclerosis stage II may indicate the early influx of C5aR-expressing cells, whereas $\mathrm{C} 5 \mathrm{~L} 2^{+}$cells increase over time.

\section{Cellular Expression of C5L2 in Human Plaques}

We next focused on cell types in human plaques that express C5L2. By using double immunostaining, C5L2expressing cells were mainly identified as macrophages (Figure 2, A and D), fewer neutrophils, prominently organized as a cluster of cells (Figure 2, B and E), and some ECs (Figure 2, C and F). Quantification of these cells reveals the presence of phagocytes, especially macrophages, as the main source of $\mathrm{C} 5 \mathrm{~L} 2$ in human plaques. $\mathrm{CD}^{+} \mathrm{T}$ cells lack C5L2, and unexpectedly C5L2 was absent in VSMCs (data not shown).

\section{Localization and Coexpression of $\mathrm{C} 5 \mathrm{~L} 2$ with $\mathrm{C} 5 \mathrm{aR}$ and oxLDL-Loaded Cells in Human Plaques}

Some scattered C5L2-expressing cells were present in the plaques, such as in stage II material, whereas many C5L2 ${ }^{+}$ cells were seen in deep lesions with lipid-containing areas, as shown in stage $\mathrm{V}$ (Figure 3A). As shown in Figure 3A, only a few C5aR-positive cells were detected in healthy control tissues (stage 0) and early-stage plaques (stage I). However, the content of these cells increased significantly on the lumen side of stage II. This remained the case in all further stages of plaque development, confirming the inflammatory nature of atherosclerotic plaques. Surprisingly, mostly lipid-loaded foam cells expressed C5L2 and C5aR in advanced stages
A

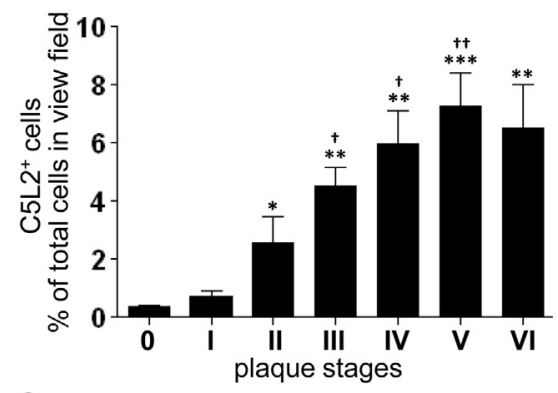

C

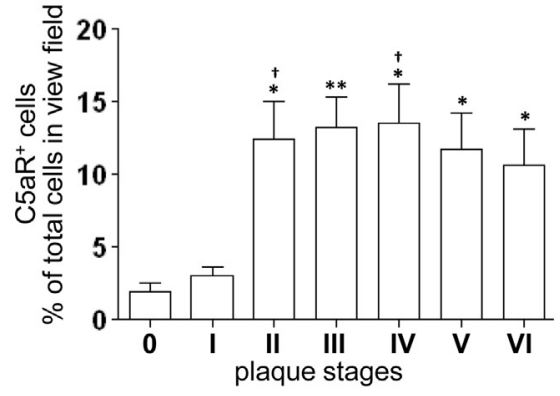

B

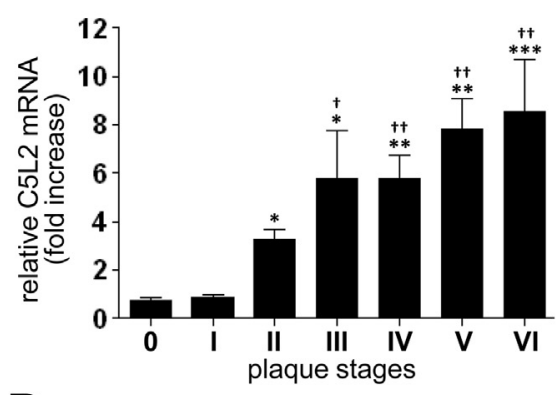

D

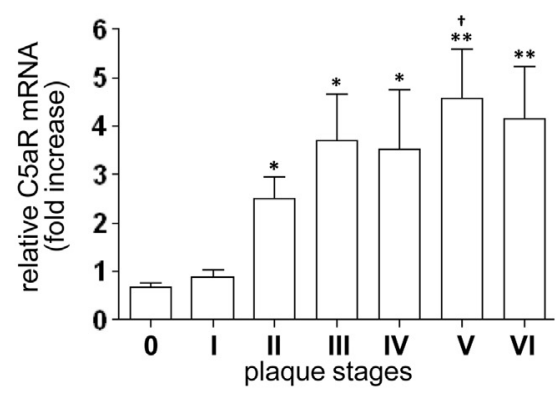

Figure $1 \mathrm{C} 5 \mathrm{~L} 2$ and $\mathrm{C} 5 \mathrm{aR}$ in human plaques. Human carotid artery sections were staged (0 to VI) and stained with antibodies against human C5L2 (A) and C5aR (CD88) (C). The positively stained cells were quantified by using 10 view fields and given as a percentage of positively stained cells to the total cells counted. The mRNA levels for C5L2 (B) and C5aR (D) in different stages of atherosclerotic plaques were determined by real-time PCR of total RNA extracted from 50 patients and represented as relative fold increase to glyceraldehyde-3-phosphate dehydrogenase in a logarithmic scale. ${ }^{*} P<0.05,{ }^{*} P<0.01$, and $* * * P<0.001$ versus control (stage 0$) ;{ }^{\dagger} P<0.05$, ${ }^{\dagger \dagger} P<0.01$ versus stage I. 
(stage V) (Figure 3A). To substantiate our observation of C5L2-expressing cells being mainly lipid loaded, we performed immunostaining on serial sections using antibodies against oxLDL, C5aR, and C5L2. C5L2-expressing cells also positively stained for malondialdehyde-oxidized LDL and C5aR (Figure 3B). These data show that C5L2-expressing cells in complicated plaque stages are lipid-loaded cells, which might be of phagocytic origin.

\section{High Expression of C5L2 Correlates with High Levels of Proinflammatory Cytokines in Human Plaques}

A remarkable number of cytokines have been linked to atherosclerosis and, hence, we measured C5a-regulated proinflammatory (IL-1 $\beta$ and TNF- $\alpha$ ) and anti-inflammatory (IL-10) cytokine levels in tissue extracts from human plaques ( $n=4$ for each stage). Low levels of IL-1 $\beta$ and TNF- $\alpha$ were found in early atherosclerosis (stages 0 to III), and high levels were found in advanced stages (Figure 4, A and B). The level of anti-inflammatory IL-10 in all plaque tissue extracts was low to nondetectable (data not shown). A direct correlation was found between the increase in release of proinflammatory cytokines and the increase in the content of $\mathrm{C} 5 \mathrm{~L}^{+}{ }^{+}$cells. This correlation was directly proportional to the lesional stage (Figure 4, C and D). To corroborate the finding that the source of IL- $1 \beta$ and TNF- $\alpha$ in the plaque is mostly C5L2-expressing phagocytes within the plaque, we performed additional in vitro analysis of $\mathrm{C} 5 \mathrm{a}$ receptor-mediated cytokine secretion.

\section{Presence of Both C5aR and C5L2 Is Important for C5a-Induced Expression of Proinflammatory Cytokines}

The correlation between C5L2-expressing cells, which were also positive for C5aR and oxLDL, and proinflammatory cytokines prompted us to pursue the importance of these receptors in cytokine secretion. To begin to investigate this, human monocytic/macrophage cell line, MM6 cells, were challenged with C5a, oxLDL, and C5aRA, as indicated in the figures. An increase of IL- $1 \beta$ and TNF- $\alpha$ was detected after C5a stimulation, which was blocked by C5aRA. Similarly, pretreatment with oxLDL, followed by stimulation with C5a, induced IL-1 $\beta$ and TNF- $\alpha$ in these cells. This was partially blocked by C5aRA, confirming the importance of $\mathrm{C} 5 \mathrm{a}$ receptors in proinflammatory cytokine secretion (Figure 5, A and B).

To check whether the up-regulation of C5L2 is critical for the expression of proinflammatory cytokines in response to C5a and oxLDL, we performed experiments on BMDMs obtained from $\mathrm{C} \mathrm{ar}^{-1-}, \mathrm{C} 5 \mathrm{l}^{-1-}$, and WT control mice. Deletion of the receptors for $\mathrm{C} 5 \mathrm{a}$ did not affect the
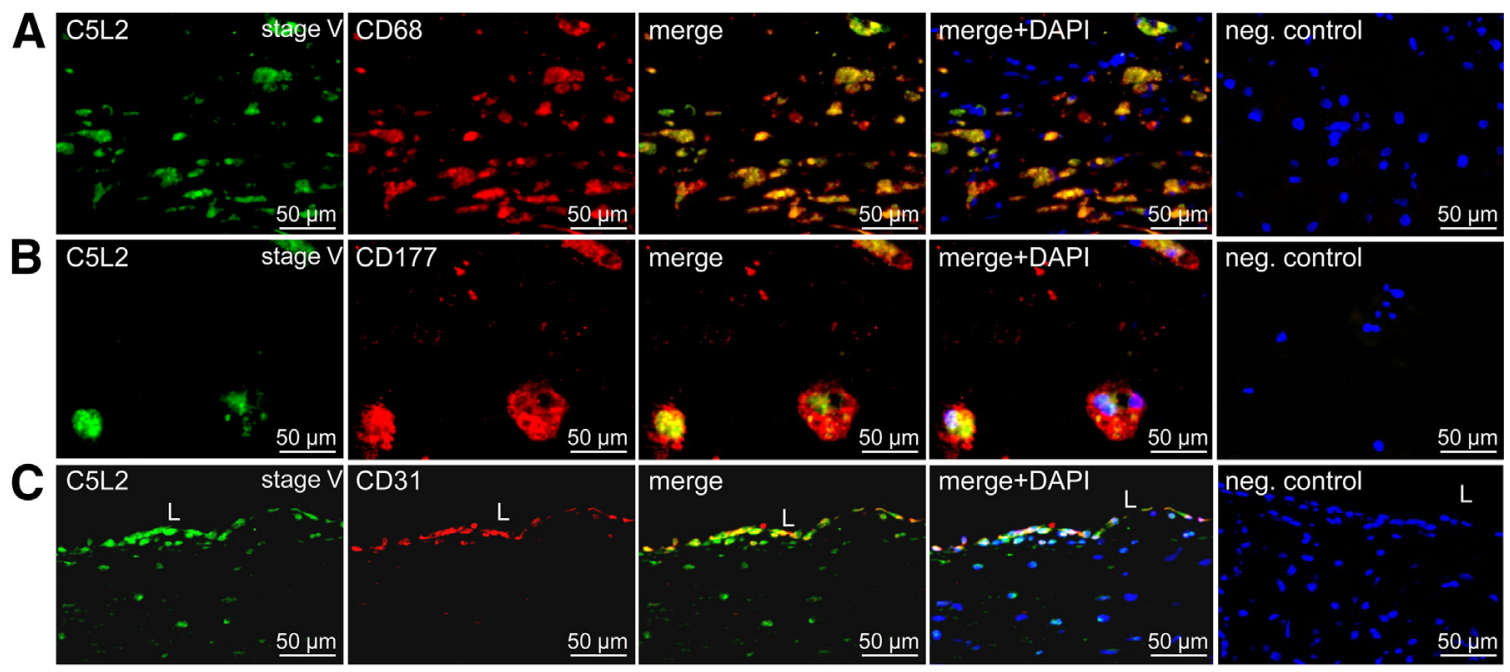

D

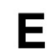

$\mathbf{F}$
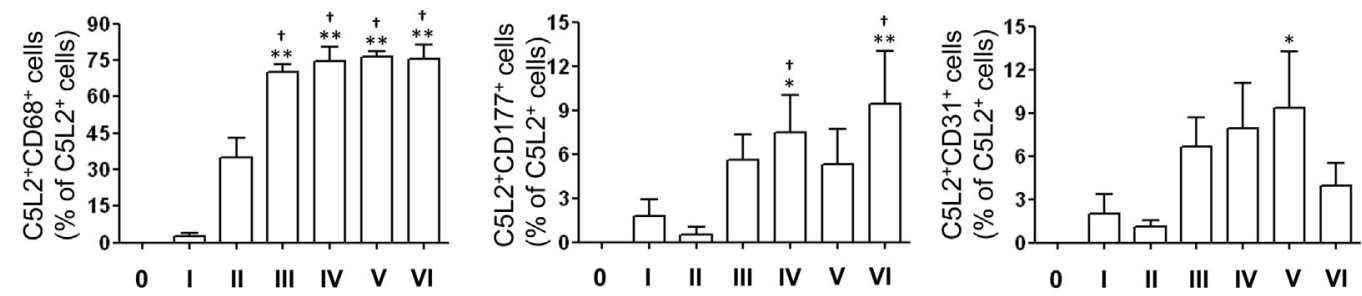

Figure 2 Cellular expression of C5L2 in human atherosclerotic plaques. Colocalization of C5L2 (green) with markers for various cell types (red) and nuclei (blue) is shown as photomicrographs. Paraffin-embedded sections were double stained for $\mathrm{C5L2}$ and $\mathrm{CD} 68^{+}$macrophages (A), clustered CD177 ${ }^{+}$neutrophils

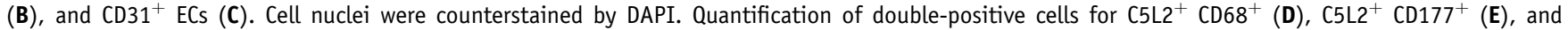
$\mathrm{C} 5 \mathrm{~L} 2^{+} \mathrm{CD} 31^{+}(\mathbf{F})$ among $\mathrm{C5L2}{ }^{+}$cells was determined in five view fields and given as a percentage of positively stained cells to the $\mathrm{C} 5 \mathrm{~L} 2^{+}$count. ${ }^{*} P<0.05$, ${ }^{*} P<0.01$ versus control (stage 0$){ }^{\dagger} P<0.05$ versus stage I. Scale bar $=50 \mu \mathrm{m}(\mathbf{A}-\mathbf{C})$. L, lumen; neg., negative. 
differentiation process, as determined by $\mathrm{F} 4 / 80$ and $\mathrm{CD} 11 \mathrm{~b}$ (Supplemental Figure S1). Cytokines (TNF- $\alpha$ and IL-1 $\beta$ ) were measured in supernatants after different conditions of stimulation with C5a, oxLDL, and C5aRA (Figure 5, D and E, and Supplemental Figure S2). Macrophages from $\mathrm{C}_{5 \mathrm{ar}}^{-1-}$ mice express $\mathrm{C} 512$ and vice versa, $C 512^{-1-}$ macrophages express C5ar. Only WT cells, which express both C5ar and C512, secreted cytokines in response to treatment with either $\mathrm{C} 5 \mathrm{a}$ or oxLDL alone. In the presence of both C5ar and C512, cytokine secretion after oxLDL pretreatment, followed by C5a stimulation, was twice as much as when stimulated with either C5a or oxLDL alone and also when one of the receptors of C5a is absent. This indicates the importance of not only ligand binding and oxLDL pre-exposure for cytokine secretion, but also the involvement of both C5a receptors in this process. A release of cytokines in ${\mathrm{C} 5 \mathrm{ar}^{-1-}}^{-}$cells in response to C5a stimulation with oxLDL pre-exposure indicates the direct role of C512. Although $\mathrm{C}_{5 \mathrm{ar}^{-1-}}$ and $\mathrm{C} 5 \mathrm{l} 2^{-/-}$macrophages did not respond to either $\mathrm{C} 5 \mathrm{a}$ or oxLDL alone, pre-exposure to oxLDL, followed by C5a stimulation, led to a significant secretion of TNF- $\alpha$ and IL- $1 \beta$. This effect was abrogated by C5aRA in $\mathrm{C}^{2} \mathrm{l} 2^{-/-}$, but not $\mathrm{C} \mathrm{ar}^{-/-}$, cells and strongly suggests the need for the presence of both C5ar and C512 for C5a and oxLDL-induced cytokine secretion, although the signaling pathway from ligation of each of these receptors is somewhat distinct.

To confirm this distinction, we checked the release of HMGB1, which has been shown to be C512, but not C5ar, dependent. Consistently, $C 512^{-1-}$ macrophages failed to release HMGB1 when exposed to oxLDL and C5a (Figure 5C). By using siRNA-mediated knockdown of $C 512$ in WT BMDMs, we could, in addition, show a C5L2-dependent secretion of TNF- $\alpha$ and IL- $1 \beta$ on oxLDL and C5a treatment (Supplemental Figure S2). Taken together, we have evidence that $\mathrm{C} 5 \mathrm{a}$-induced proinflammatory cytokine production under atherogenic conditions requires both receptors of $\mathrm{C5a}$.

\section{C5L2 Promotes Mononuclear Cell Arrest on TNF- $\alpha$-Stimulated ECs by Enhancing the Expression of Integrins}

The arrest of monocytes to the inflamed endothelium is triggered by integrins on monocytes and adhesion molecules and chemokines on ECs. Because this is a key step in the initiation of atherogenesis before the proinflammatory profile kicks in, we pursued the possible role of C5L2 at this

\section{A $\mathrm{C} 5 \mathrm{~L} 2$ and $\mathrm{C} 5 \mathrm{aR}$ in plaques}

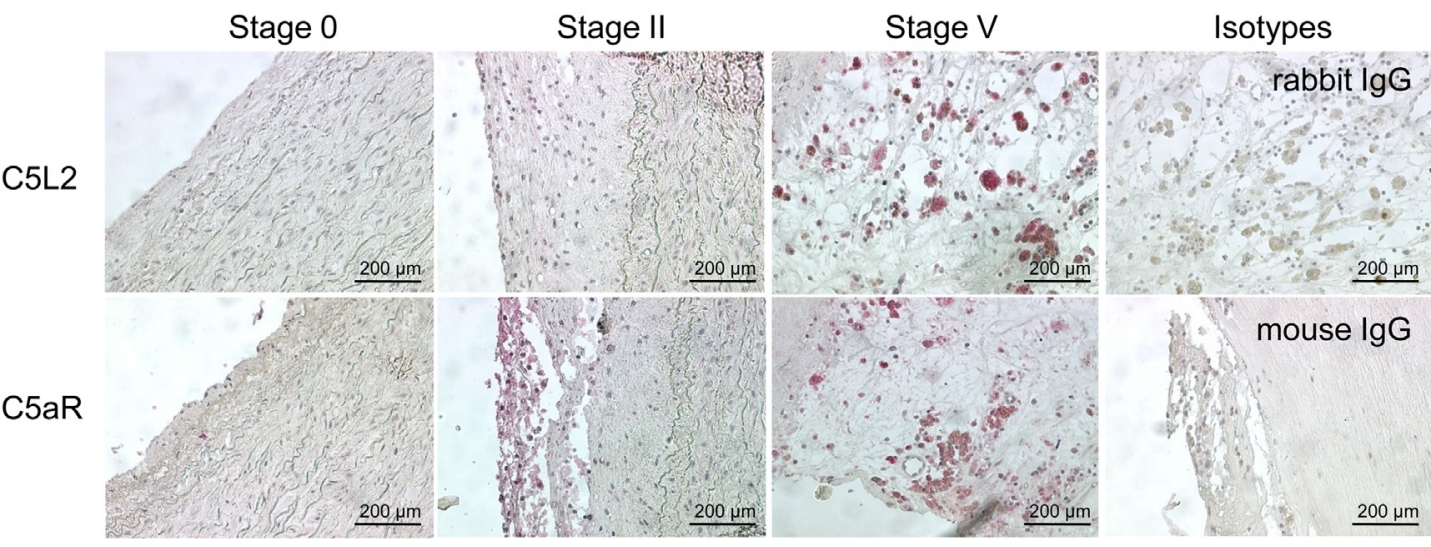

B Colocalization of C5L2 with oxLDL and C5aR
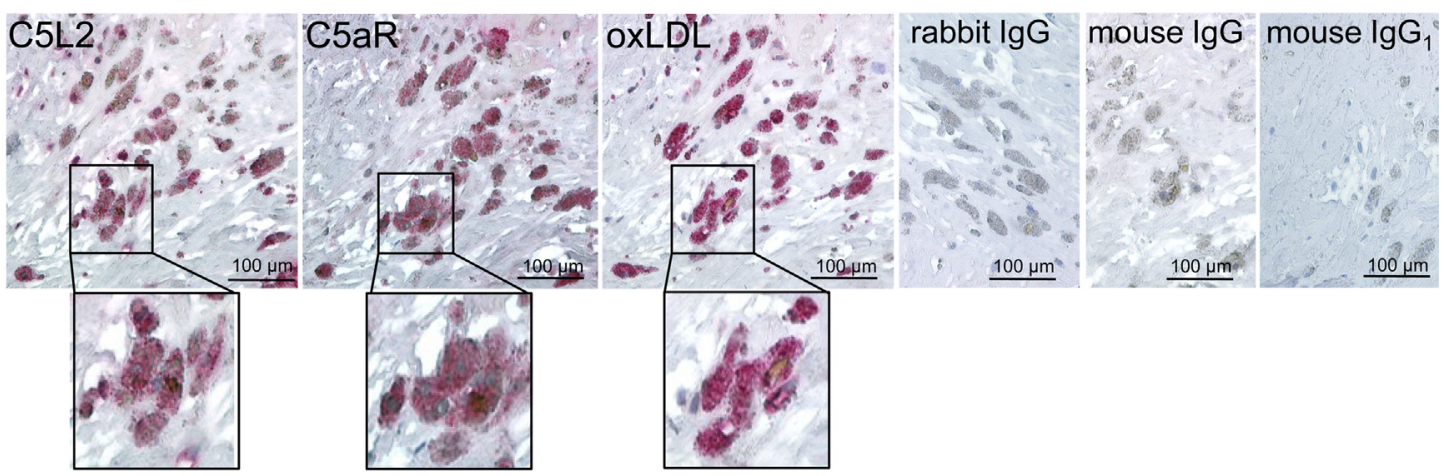

Figure 3 Localization and expression of $\mathrm{C} 5 \mathrm{~L} 2, \mathrm{C} 5 \mathrm{aR}$, and $0 x \mathrm{LDL}$ in human plaques. The expression and localization of $\mathrm{C} 5 \mathrm{~L} 2$ in healthy (stage 0 ), early plaque specimen (stage II), and advanced lesion (stage V) were detected by IHC avidin-biotin complex (ABC) staining on paraffin-embedded sections. A: $\mathrm{C}_{5} \mathrm{~L} 2$ and $\mathrm{C5aR}$ in large lipid-loaded cells are shown in advanced stages. B: Anti-malondealdehyde oxLDL ${ }^{+}$cells colocalized with $\mathrm{C} 5 \mathrm{~L} 2$ and $\mathrm{C5aR}$ in frozen serial sections of advanced plaques (stage V, $n=9$ ) stained by ABC. Magnified images are shown in black boxes representing the areas of interest. Cell nuclei were stained with Mayer's Hämalaun. Isotype control staining for each type of antibodies is shown. 
A

Cytokines in plaques

IL-1 $\beta$

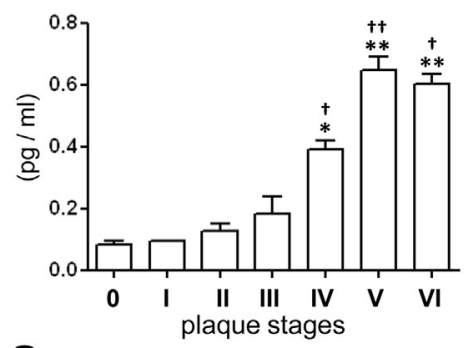

C

Correlation of $\mathrm{C} 5 \mathrm{~L} 2$ with cytokines in plaques

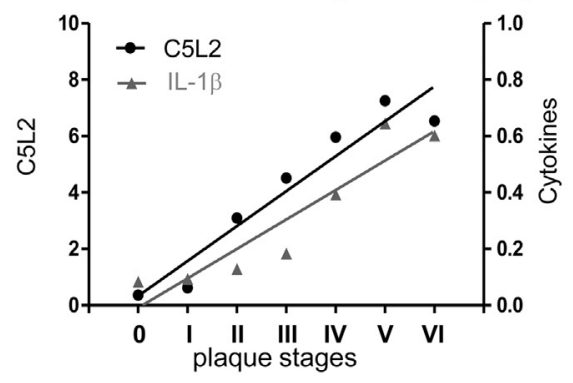

B

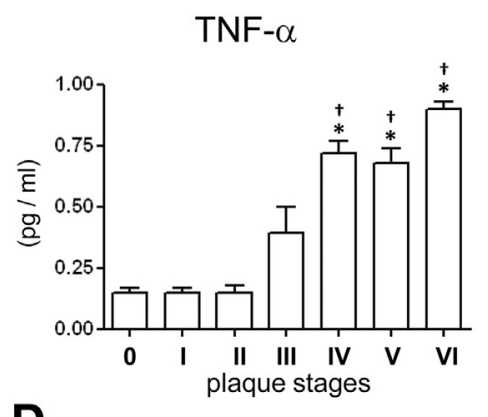

D

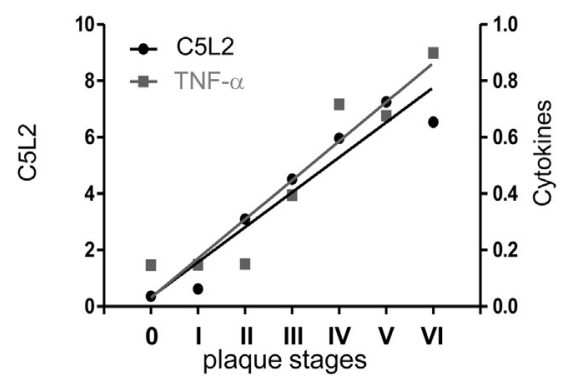

Figure 4 High expression of C5L2 correlates with high levels of proinflammatory cytokines, IL$1 \beta$ and TNF- $\alpha$, in human atherosclerosis. Tissue extracts of human plaque samples were analyzed by ELISA for concentration of IL-1 $\beta$ (A) and TNF- $\alpha$ (B) in different stages of plaques. Correlations between C5L2 and IL-1 $\beta$ (C) or TNF- $\alpha$ (D) in different stages of plaque development were analyzed. ${ }^{*} P<0.05,{ }^{*} * P<0.01$ versus control (stage 0$) ;{ }^{\dagger} P<0.05,{ }^{\dagger \dagger} P<0.01$ versus stage I. initial stage of atherogenesis. To check whether $C 5 l 2$ deficiency will alter PBMC adhesion rates in vitro, we performed a flow adhesion assay to investigate the arrest of perfused PBMCs on TNF- $\alpha$-activated SVECs. As expected, WT PBMCs adhered nicely to TNF- $\alpha$-activated SVECs. This was, however, impaired not only by the deletion of $\mathrm{C} 5 \mathrm{l} 2$ but also by $\mathrm{C} 5 \mathrm{ar}$ deletion (Figure 6, A and $\mathrm{B})$, indicating that the receptors of C5a may promote atherogenic leukocyte recruitment. To further investigate the cause of this in vitro impaired adhesion, we checked the expression of the $\beta 2$ integrin $C D 11 \mathrm{~b}$, which has been shown to be regulated in part by $\mathrm{C} 5 \mathrm{a},{ }^{20}$ by flow cytometry. Deletion of C5a receptors led to significantly reduced expression of CD11b (Figure 6C), which may explain the impaired PBMC arrest on $C 512$ or C5ar deletion.

\section{Discussion}

Herein, we demonstrate four major findings. i) We provide new insights into the biological characteristics of C5L2 in the context of human atherosclerosis by revealing the presence of C5L2 in human plaques and determining C5L2expressing cells in them. ii) We report the direct correlation of high expression of C5L2 in advanced plaques with high levels of proinflammatory cytokines, TNF- $\alpha$ and IL- $1 \beta$, which may indicate the proinflammatory role of C5L2 in human atherosclerosis. iii) We ascertain the contributory role of C5L2 for cytokine secretion and identify the importance of the presence of both C5ar and C512 for maximal induction of proinflammatory cytokines, IL-1 $\beta$ and
TNF- $\alpha$, in response to C5a and oxLDL. The combined effect of C5a and oxLDL on BMDMs isolated from WT, $\mathrm{C} \mathrm{ar}^{-/-}$, and $\mathrm{C}^{2} \mathrm{l}^{-/-}$mice is also described. Interestingly, PBMCs lacking either of these receptors adhere poorly to activated ECs under flow conditions in vitro. iv) We provide primary information on the stage-dependent expression of both C5a receptors in human atherogenesis and show the significant recruitment of C5aR-expressing cells in early stages of atherogenesis.

Studies earlier showed the involvement of C5a and C5aR (CD88) in atherosclerosis and restenosis. C5a was present in human coronary lesions, and its higher levels were associated with late lumen loss of drug-eluting stents. ${ }^{21,22}$ Macrophages stimulated with $\mathrm{C} 5 \mathrm{a}$ showed increased mRNA levels of matrix metalloproteinases 1 and 9 , indicating the role of locally produced $\mathrm{C} 5 \mathrm{a}$ in plaque destabilization. ${ }^{21}$ In our previous study, we revealed the critical role of C5ar in restenosis of vascular-damaged mice. Short-term blockade of C5ar limited neointimal hyperplasia with reduced plaque inflammation, whereas long-term treatment stabilized the plaques, because of increased migration of VSMCs, but did not affect the plaque size. ${ }^{5}$ Therefore, we analyzed herein the expression of both C5a receptors in different stages of human atherosclerotic plaques to elucidate an option for the stage-dependent treatment of atherosclerosis.

We found the presence of C5aR-expressing cells in human atherosclerotic plaque specimens, confirming the previous study on $\mathrm{C} 5 \mathrm{aR}$ expression in advanced plaques. ${ }^{23}$ In all stages of plaque progression, C5aR-positive cells and C5aR-mRNA were detected. This correlates positively with increasing degree of plaque complexity. Interestingly, early 


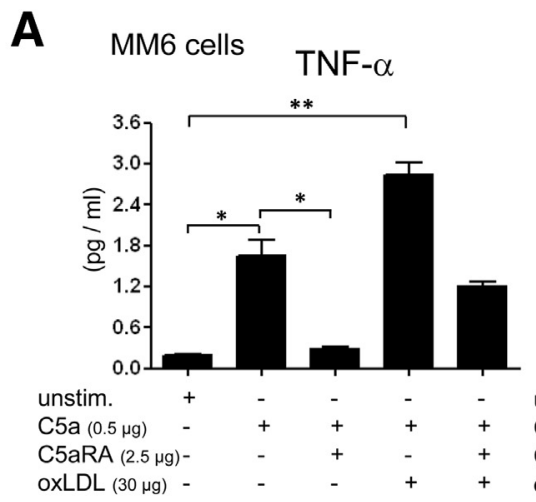

D BMDMs from mice

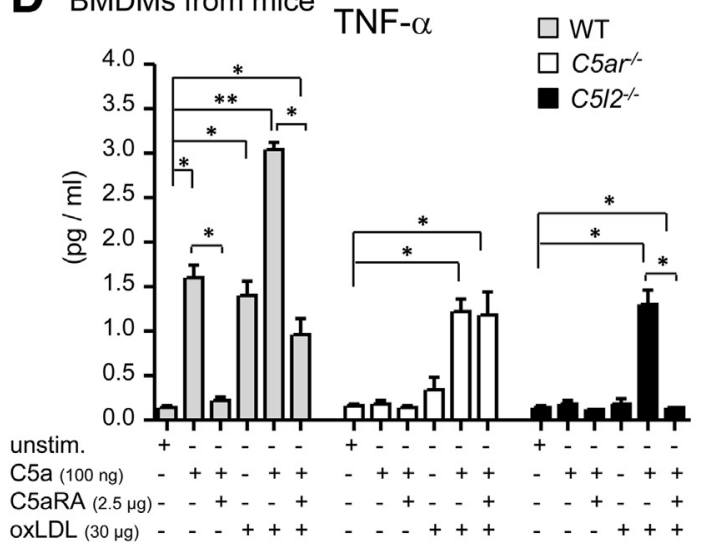

B

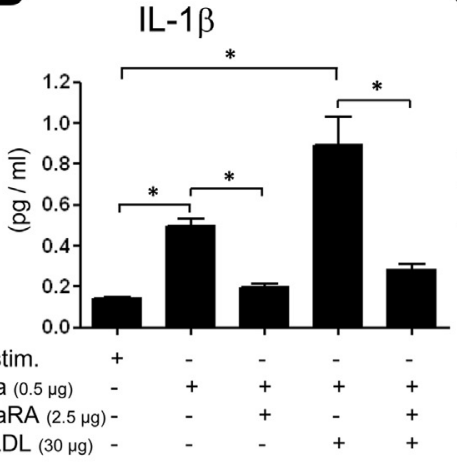

C BMDMs from mice

HMGB1

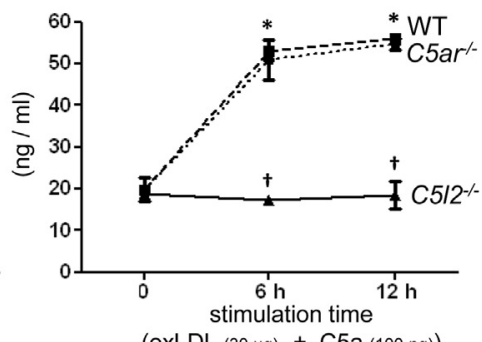

$($ oxLDL $(30 \mu g)+$ C5a (100 ng) $)$

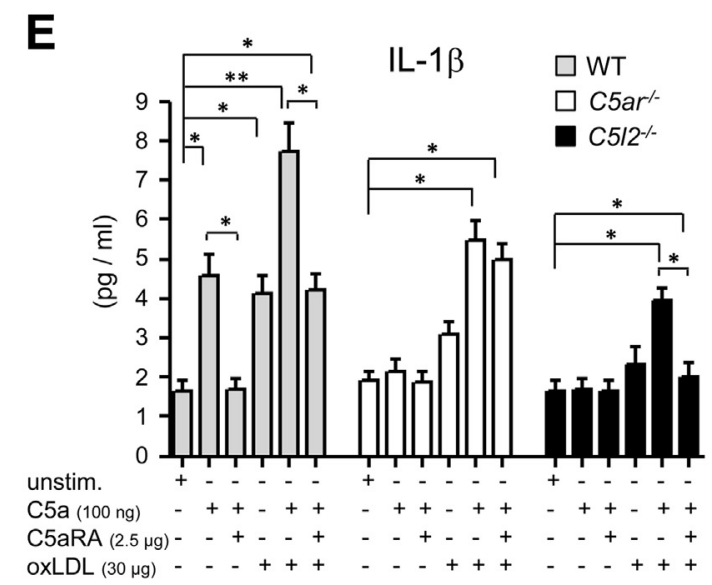

Figure 5 Critical role of both C5a receptors for $\mathrm{C} 5 \mathrm{a}$-induced cytokine secretion. $\mathbf{A}$ and $\mathbf{B}$ : TNF- $\alpha$ and IL-1 $\beta$ concentrations were measured in supernatants of unstimulated, C5a-stimulated, oxLDL-stimulated, and C5aRA-pretreated MM6 cells. TNF- $\alpha$ (D) and IL-1 $\beta$ (E) concentration and HMGB1 release (C), respectively, were measured by ELISA after stimulation with $\mathrm{C} 5 \mathrm{a}$ and oxLDL, alone or combined and with or without $\mathrm{C5aRA}$ in macrophages isolated from WT', $\mathrm{C5ar}^{-/-}$, and C5 $12^{-/-}$mice. ${ }^{*} P<0.05,{ }^{* *} P<0.01$, control versus treated cells; ${ }^{\dagger} P<0.05, C 512^{-/-}$versus WT and $C 5 \mathrm{ar}^{-/-}$. unstim., unstimulated.

atherosclerotic lesions significantly express more C5aR than C5L2, which may indicate that inflammatory cells are initially recruited into the damaged vessels through $\mathrm{C} 5 \mathrm{aR}$. Inhibiting the recruitment of inflammatory C5aR-expressing cells in the early stages of plaque development could be an effective treatment strategy. This is consistent with our previous data that short-term blockade of the recruitment of
C5aR-expressing cells in the early phase of mouse atherosclerosis was effective. ${ }^{5}$ A therapeutic strategy that takes advantage of blocking the recruitment of C5aR-expressing cells in the initial phase of atherosclerosis might be protective against inflammation in atherosclerosis.

More important, our study presents the first evidence for the presence of the second alternative receptor of C5a,

A Mouse PBMC arrest on SVEC monolayers

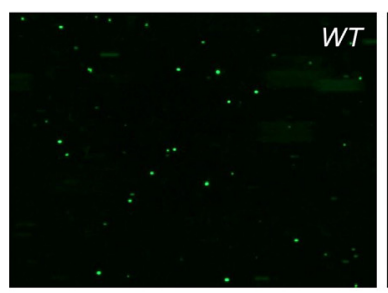

B

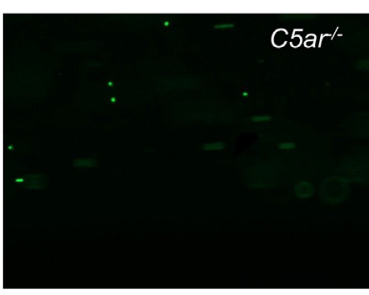

C

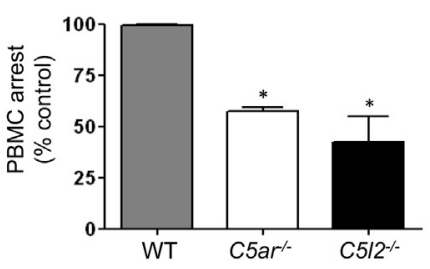

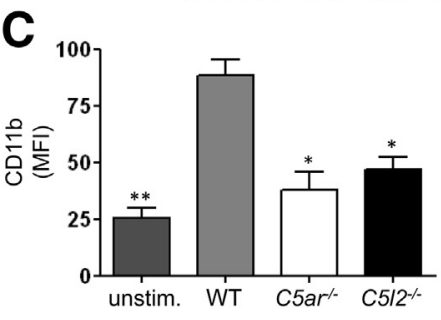

$\mathrm{C} 512^{-1-}$

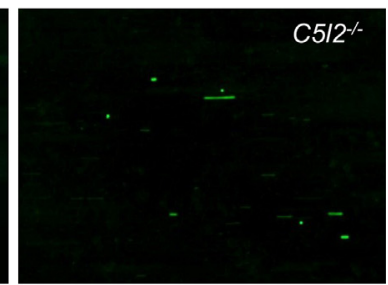

Figure 6 C5a receptors are crucial for integrin expression and TNF- $\alpha$-induced mononuclear cell arrest on SVEC. PBMCs were isolated from WT, $\mathrm{C5} \mathrm{ar}^{-/-}$, and $C 512^{-/-}$mice, calcein-AM labeled, and perfused over TNF- $\alpha$-stimulated SVEC. Shown are representative images of three independent experiments, indicating adhesion rates (A) and quantification of arrested PBMCs expressed as percentage of WT control (B). C: Flow cytometric analysis of CD11b on the surface of PBMCs from WT, ${\mathrm{C} 5 \mathrm{ar}^{-}-}^{-}$, and $\mathrm{C}_{512} \mathrm{~L}^{-/-}$ mice. Cells were treated with $50 \mathrm{ng} / \mathrm{mL}$ phorbol myristate acetate for 15 minutes before antibody staining. Untreated cells served as control (striped bar). The graph represents means \pm SEM of PBMCs isolated from four mice per group. ${ }^{\star} P<0.05$, ${ }^{* *} P<0.01$ versus WT control. MFI, mean fluorescence intensity; unstim., unstimulated. 
C5L2, in human plaques. In contrast to C5aR, C5L2 was rarely observed in early stages of atherosclerosis. However, expression of C5L2 increases over time without significant differences in the advanced stages of the disease. C5L2 was found to be expressed mostly in macrophages and was located in the shoulder, lipid-loaded areas around necrotic cores, and plaque hemorrhage with inflammatory infiltrates. Interestingly, C5L2-expressing cells contained oxLDL and colocalized with C5aR in advanced and complicated plaques. C5L2 is generally seen to be expressed in similar tissue and cellular locations as $\mathrm{C} 5 \mathrm{aR}$, in agreement with their adjacent location on the genome. ${ }^{6} \mathrm{C} 5 \mathrm{~L} 2$ has been shown to predominantly be an intracellular receptor that is consequently activated as a result of $\mathrm{C} 5 \mathrm{aR}$ activation in human neutrophils. ${ }^{13}$ However, there is also evidence for cell type-dependent expression of $\mathrm{C} 5 \mathrm{~L} 2$ on the cell surface. $^{24}$

Our data show the presence of higher mRNA levels for C5L2 than C5aR in all atherosclerotic stages. However, in previous studies, C5L2 was shown to be expressed in neutrophils, macrophages, and immature dendritic cells, along with C5aR, with significantly reduced mRNA. ${ }^{6}$ Moreover, the expression of C512 in hyperlipidemic Apoe ${ }^{-1-}$ mice has been reported, in which lower levels of C512-mRNA in different ages of mice were observed in $\mathrm{Apoe}^{-/-}$when compared with WT controls. The down-regulation of C512mRNA occurred in aorta, liver, and spleen, indicating that this effect is due to the lack of Apoe in these mice. ${ }^{15}$ Our findings herein clearly contradict this observation, and further studies are needed to unravel this, taking into account that the human vasculature is pretty much different from the mouse.

VSMCs in plaques expressed $\mathrm{C}_{5} \mathrm{aR}^{5,23}$; therefore, the absence of C5L2 reported herein was unforeseen. We previously reported C5aR expression at mRNA and protein levels in human and mouse VSMCs. In the context of arterial neointima formation, we identified a specific role of the C5aR in the regulation of vascular cell adhesion molecule-1 and plasminogen activator inhibitor-1 in VSMCs. ${ }^{5}$ Herein, we conclude that the expression of C5aR and C5L2 can be tissue and cell type specific, confirming previous reports. ${ }^{25-27}$

The direct correlation of highly expressed C5L2 in advanced plaques with high levels of proinflammatory cytokines, IL-1 $\beta$ and TNF- $\alpha$, may indicate the proinflammatory role of C5L2 in human atherosclerosis. TNF- $\alpha$ regulates several cell functions, and a deficiency of TNF- $\alpha$ in mouse shows a decrease in atherosclerosis with reduction of inflammation by inducing oxLDL uptake in macrophages. ${ }^{28}$ Similarly, IL-1 $\beta$ is important in regulating atherosclerotic inflammation ${ }^{29}$ and has been thought to be of greater relevance to human atherosclerosis. IL-1 $\beta$-deficient mice were shown to have less atherosclerosis, ${ }^{30}$ and IL-1 $\beta$ inhibition has been proposed to reduce major cardiovascular events in humans. ${ }^{31}$ Intuitively, the in vitro data may indicate $\mathrm{C} 512$ as a proatherogenic factor that needs to be studied in detail using in vivo atherosclerosis models.
In direct contrast to both the decoy receptor ${ }^{10}$ and antiinflammatory $\beta$-arrestin models of C512 function, ${ }^{13}$ a proinflammatory role of $\mathrm{C} 5 \mathrm{~L} 2$ has been described in some studies. It has been shown that C5L2 appears to be a trigger in C5a-induced up-regulation of IL-6 and TNF- $\alpha$ in neutrophils. ${ }^{12}$ A recent study underlined the proinflammatory role of C5L2 in C5a-primed neutrophils for anti-neutrophil cytoplasmic antibody-induced activation. ${ }^{32}$ Rittirsch et $\mathrm{al}^{14}$ showed that genetic deficiency- or antibodymediated blockade of $\mathrm{C} 512$ provided modest protection from cecal ligation and puncture-mediated sepsis. This report, in addition, showed that signaling through C512, but not C5ar, led to release of the inflammatory protein, HMGB $1 .{ }^{14}$ To check whether the up-regulation of C5L2 is responsible for the high expression of proinflammatory cytokines in response to C5a and oxLDL, we performed experiments on BMDMs obtained from $\mathrm{C} \mathrm{ar}^{-/-}, \mathrm{C} \mathrm{l}^{-/-}$, and WT control mice. Because most C5L2-expressing cells were identified as macrophages, BMDMs were analyzed for cytokine release. We found that only WT cells, which express both C5ar and C512, were able to produce proinflammatory cytokines when compared with $\mathrm{C} \mathrm{ar}^{-1-}$ and $C 5 l 2^{-/-}$cells in response to either oxLDL or C5a stimulation alone. Moreover, WT cells released twice as much proinflammatory cytokines than was released from $\mathrm{C}_{5 \mathrm{ar}^{-/-}}$ and $\mathrm{C} \mathrm{l} 2^{-/-}$cells in response to C5a stimulation with oxLDL pre-exposure and also than C5a and oxLDL alone. These data suggest the importance of the presence of both receptors for maximal induction of proinflammatory cytokines and confirm a previous study that protection from high-grade sepsis, which resulted in 100\% lethality, was achieved only by the combined inhibition of C512 and C5ar. ${ }^{14}$ In addition, cooperation between the two receptors has been demonstrated in human neutrophils ${ }^{13}$ and, recently, C512 was found to heterodimerize with C5ar with subsequent Akt phosphorylation in macrophages and adipocytes, and internalization on stimulation by ligands. ${ }^{33}$

Furthermore, the release of cytokines in $\mathrm{C}^{\mathrm{ar}} \mathrm{ar}^{--}$and $C 5 l 2^{-1-}$ cells only in response to C5a stimulation with oxLDL pre-exposure, and not stimulation with C5a and oxLDL alone, underlines an important role of oxLDL in human atherosclerosis and the combined effect of ligand binding and oxLDL pre-exposure. OxLDL alone was able to induce cytokines in WT cells, indicating involvement of oxLDL receptor-mediated cytokine secretion. Several receptors on the macrophage can recognize and internalize oxLDL, leading to its degradation. ${ }^{34} \mathrm{CD} 36$, an archetypal pattern-recognition receptor, has been linked to the pathogenesis of atherosclerosis through its recognition of modified endogenous ligands, including oxLDL. ${ }^{35}$ Both C5ar and $\mathrm{C} 512$ have been shown to differentially regulate $\mathrm{CD} 36,{ }^{25,36}$ and one may speculate the need for both receptors for the regulation of CD36 in a yet unknown manner.

Further analysis showed a release of cytokines in $\mathrm{C}_{5} \mathrm{ar}^{-/-}$ cells in response to $\mathrm{C} 5 \mathrm{a}$ stimulation with oxLDL 
pre-exposure, which indicates the direct role of $\mathrm{C} 512$ in this process. This may occur because of the ligand binding of C512 in interaction with oxLDL in macrophages. How does C5a gain access to C512? Although C5L2 is mostly intracellular, we suppose that oxLDL pre-exposure may induce surface expression of C512 in these cells. There is also evidence that at least a portion of C512 protein is expressed as a cell surface receptor. In nonpermeabilized neutrophils, monocytes, and mast cell line HMC-1, C512 expression has been demonstrated to be low and highly variably expressed, but to be present at the cell surface. ${ }^{24,37}$ Interestingly, there is a positive correlation between neutrophil C5L2 surface expression and sepsis survival rates. This suggests that the ratio of surface/intracellular expression of this receptor may be dynamic and change, depending on the disease state. ${ }^{38}$ $\mathrm{C}_{5} \mathrm{l} 2^{-/-}$cells released proinflammatory cytokines in response to C5a stimulation with oxLDL pre-exposure, which was completely blocked by C5aRA. These data underline again the importance of the presence of both receptors for optimal cytokine secretion in mouse macrophages. Whether C5aR or C5L2 plays a role in recognition of oxLDL, thereby leading to the uptake and a combined effect of ligand binding with oxLDL, needs to be examined. A C512dependent release of the proinflammatory mediator, HMGB1, in the presence of both C5a and lipopolysaccharide has been reported. ${ }^{14}$ Consistently, we could show that BMDMs lacking C5l2 failed to release HMGB1 when exposed to C5a and oxLDL. This corroborates a proinflammatory role of C512 in a broad manner.

Adhesion of mononuclear cells to inflamed endothelium that precedes the accumulation of monocytes in the intima is a key step in atherogenesis. ${ }^{39}$ In vitro data that C5a receptors promote mononuclear cell adhesion to TNF$\alpha$-activated ECs by enhancing the expression of the $\beta_{2}$ integrin CD11b could imply that C512 and C5ar may exhibit proatherogenic functions.

To reveal the role of $\mathrm{C} 5 \mathrm{a}$ receptors in atherosclerosis, it is necessary to investigate the functional role of both receptors in knockout mouse models under hypercholesterolemic conditions, which is beyond the scope of this study.

In summary, our study identifies the stage-dependent expression of C5aR and C5L2 in human atherogenesis and supports the notion that C5aRA could be a potential treatment for atherosclerosis and restenosis. Our data present the first insight into the biological characteristics of C5L2 in the vasculature in the context of human atherosclerosis. The direct correlation of $\mathrm{C} 5 \mathrm{~L} 2$, with atherosclerotic lesion progression and proinflammatory cytokines, may indicate the proinflammatory character of $\mathrm{C} 5 \mathrm{~L} 2$, which needs to be pursued in the future by applying in vivo mouse models.

\section{Acknowledgments}

We thank Roya Soltan, Yuan Kong, Melanie Garbe, and Sabine Winkler for their excellent technical assistance.

\section{Supplemental Data}

Supplemental material for this article can be found at http://dx.doi.org/10.1016/j.ajpath.2014.04.004.

\section{References}

1. Packard RR, Lichtman AH, Libby P: Innate and adaptive immunity in atherosclerosis. Semin Immunopathol 2009, 31:5-22

2. Binder CJ, Chang MK, Shaw PX, Miller YI, Hartvigsen K, Dewan A, Witztum JL: Innate and acquired immunity in atherogenesis. Nat Med 2002, 8:1218-1226

3. Gerard C, Gerard NP: C5A anaphylatoxin and its seven transmembranesegment receptor. Annu Rev Immunol 1994, 12:775-808

4. Laudes IJ, Chu JC, Huber-Lang M, Guo RF, Riedemann NC, Sarma JV, Mahdi F, Murphy HS, Speyer C, Lu KT, Lambris JD, Zetoune FS, Ward PA: Expression and function of C5a receptor in mouse microvascular endothelial cells. J Immunol 2002, 169: 5962-5970

5. Shagdarsuren E, Bidzhekov K, Mause SF, Simsekyilmaz S, Polakowski T, Hawlisch H, Gessner JE, Zernecke A, Weber C: C5a receptor targeting in neointima formation after arterial injury in atherosclerosis-prone mice. Circulation 2010, 122:1026-1036

6. Monk PN, Scola AM, Madala P, Fairlie DP: Function, structure and therapeutic potential of complement C5a receptors. Br J Pharmacol 2007, 152:429-448

7. Boor P, Konieczny A, Villa L, Schult AL, Bucher E, Rong S, Kunter U, van Roeyen CR, Polakowski T, Hawlisch H, Hillebrandt S, Lammert F, Eitner F, Floege J, Ostendorf T: Complement C5 mediates experimental tubulointerstitial fibrosis. J Am Soc Nephrol 2007, 18: $1508-1515$

8. Godau J, Heller T, Hawlisch H, Trappe M, Howells E, Best J, Zwirner J, Verbeek JS, Hogarth PM, Gerard C, Van Rooijen N, Klos A, Gessner JE, Kohl J: C5a initiates the inflammatory cascade in immune complex peritonitis. J Immunol 2004, 173:3437-3445

9. Chen NJ, Mirtsos C, Suh D, Lu YC, Lin WJ, McKerlie C, Lee T, Baribault H, Tian H, Yeh WC: C5L2 is critical for the biological activities of the anaphylatoxins C5a and C3a. Nature 2007, 446:203-207

10. Scola AM, Johswich KO, Morgan BP, Klos A, Monk PN: The human complement fragment receptor, $\mathrm{C} 5 \mathrm{~L} 2$, is a recycling decoy receptor. Mol Immunol 2009, 46:1149-1162

11. Gerard NP, Lu B, Liu P, Craig S, Fujiwara Y, Okinaga S, Gerard C: An anti-inflammatory function for the complement anaphylatoxin C5abinding protein, C5L2. J Biol Chem 2005, 280:39677-39680

12. Gao H, Neff TA, Guo RF, Speyer CL, Sarma JV, Tomlins S, Man Y, Riedemann NC, Hoesel LM, Younkin E, Zetoune FS, Ward PA: Evidence for a functional role of the second C5a receptor C5L2. FASEB J 2005, 19:1003-1005

13. Bamberg CE, Mackay CR, Lee H, Zahra D, Jackson J, Lim YS Whitfeld PL, Craig S, Corsini E, Lu B, Gerard C, Gerard NP: The C5a receptor $(\mathrm{C} 5 \mathrm{aR}) \mathrm{C} 5 \mathrm{~L} 2$ is a modulator of $\mathrm{C} 5 \mathrm{aR}$-mediated signal transduction. J Biol Chem 2010, 285:7633-7644

14. Rittirsch D, Flierl MA, Nadeau BA, Day DE, Huber-Lang M, Mackay CR, Zetoune FS, Gerard NP, Cianflone K, Kohl J, Gerard C, Sarma JV, Ward PA: Functional roles for C5a receptors in sepsis. Nat Med 2008, 14:551-557

15. Manthey HD, Thomas AC, Shiels IA, Zernecke A, Woodruff TM, Rolfe B, Taylor SM: Complement C5a inhibition reduces atherosclerosis in ApoE-/- mice. FASEB J 2011, 25:2447-2455

16. Woodruff TM, Costantini KJ, Crane JW, Atkin JD, Monk PN Taylor SM, Noakes PG: The complement factor C5a contributes to pathology in a rat model of amyotrophic lateral sclerosis. J Immunol 2008, 181:8727-8734

17. Stary HC, Chandler AB, Glagov S, Guyton JR, Insull W Jr, Rosenfeld ME, Schaffer SA, Schwartz CJ, Wagner WD, Wissler RW: 
A definition of initial, fatty streak, and intermediate lesions of atherosclerosis: a report from the Committee on Vascular Lesions of the Council on Arteriosclerosis, American Heart Association. Arterioscler Thromb Vasc Biol 1994, 14:840-856

18. Stary HC, Chandler AB, Dinsmore RE, Fuster V, Glagov S, Insull W Jr, Rosenfeld ME, Schwartz CJ, Wagner WD, Wissler RW: A definition of advanced types of atherosclerotic lesions and a histological classification of atherosclerosis: a report from the Committee on Vascular Lesions of the Council on Arteriosclerosis, American Heart Association. Arterioscler Thromb Vasc Biol 1995, 15:1512-1531

19. Asare Y, Shagdarsuren E, Schmid JA, Tilstam PV, Grommes J, El Bounkari O, Schutz AK, Weber C, de Winther MP, Noels H, Bernhagen J: Endothelial CSN5 impairs NF-kappaB activation and monocyte adhesion to endothelial cells and is highly expressed in human atherosclerotic lesions. Thromb Haemost 2013, 110:141-152

20. Fujiu T, Kato M, Kimura H, Tachibana A, Suzuki M, Nako Y, Morikawa A: Cellular adhesion is required for effector functions of human eosinophils via G-protein coupled receptors. Ann Allergy Asthma Immunol 2002, 89:90-98

21. Speidl WS, Kastl SP, Hutter R, Katsaros KM, Kaun C, Bauriedel G, Maurer G, Huber K, Badimon JJ, Wojta J: The complement component $\mathrm{C} 5 \mathrm{a}$ is present in human coronary lesions in vivo and induces the expression of MMP-1 and MMP-9 in human macrophages in vitro. FASEB J 2011, 25:35-44

22. Speidl WS, Katsaros KM, Kastl SP, Zorn G, Huber K, Maurer G, Wojta J, Christ G: Coronary late lumen loss of drug eluting stents is associated with increased serum levels of the complement components C3a and C5a. Atherosclerosis 2010, 208:285-289

23. Oksjoki R, Laine P, Helske S, Vehmaan-Kreula P, Mayranpaa MI, Gasque P, Kovanen PT, Pentikainen MO: Receptors for the anaphylatoxins $\mathrm{C} 3 \mathrm{a}$ and $\mathrm{C} 5 \mathrm{a}$ are expressed in human atherosclerotic coronary plaques. Atherosclerosis 2007, 195:90-99

24. Otto M, Hawlisch H, Monk PN, Muller M, Klos A, Karp CL, Kohl J: C5a mutants are potent antagonists of the C5a receptor (CD88) and of C5L2: position 69 is the locus that determines agonism or antagonism. J Biol Chem 2004, 279:142-151

25. Roy C, Gupta A, Fisette A, Lapointe M, Poursharifi P, Richard D, Lu H, Lu B, Gerard N, Gerard C, Cianflone K: C5a receptor deficiency alters energy utilization and fat storage. PLoS One 2013, 8:e62531

26. Yuan J, Gou SJ, Huang J, Hao J, Chen M, Zhao MH: C5a and its receptors in human anti-neutrophil cytoplasmic antibody (ANCA)associated vasculitis. Arthritis Res Ther 2012, 14:R140

27. Tokodai $\mathrm{K}$, Goto M, Inagaki A, Imura T, Nakanishi W, Satomi S: Expression of receptors for anaphylatoxins $\mathrm{C} 3 \mathrm{a}$ and $\mathrm{C} 5 \mathrm{a}$ on rat islet preparations. Transplant Proc 2011, 43:3179-3180
28. Ohta H, Wada H, Niwa T, Kirii H, Iwamoto N, Fujii H, Saito K, Sekikawa K, Seishima M: Disruption of tumor necrosis factor-alpha gene diminishes the development of atherosclerosis in ApoEdeficient mice. Atherosclerosis 2005, 180:11-17

29. Dinarello CA: A clinical perspective of IL-1beta as the gatekeeper of inflammation. Eur J Immunol 2011, 41:1203-1217

30. Alexander MR, Moehle CW, Johnson JL, Yang Z, Lee JK, Jackson CL, Owens GK: Genetic inactivation of IL-1 signaling enhances atherosclerotic plaque instability and reduces outward vessel remodeling in advanced atherosclerosis in mice. J Clin Invest 2012, 122:70-79

31. Ridker PM, Thuren T, Zalewski A, Libby P: Interleukin-1beta inhibition and the prevention of recurrent cardiovascular events: rationale and design of the Canakinumab Anti-inflammatory Thrombosis Outcomes Study (CANTOS). Am Heart J 2011, 162:597-605

32. Hao J, Wang C, Yuan J, Chen M, Zhao MH: A pro-inflammatory role of C5L2 in C5a-primed neutrophils for ANCA-induced activation. PLoS One 2013, 8:e66305

33. Poursharifi P, Lapointe M, Petrin D, Devost D, Gauvreau D, Hebert TE, Cianflone K: C5L2 and C5aR interaction in adipocytes and macrophages: insights into adipoimmunology. Cell Signal 2012, 25 : 910-918

34. Itabe H: Oxidized low-density lipoproteins: what is understood and what remains to be clarified. Biol Pharm Bull 2003, 26:1-9

35. Kunjathoor VV, Febbraio M, Podrez EA, Moore KJ, Andersson L, Koehn S, Rhee JS, Silverstein R, Hoff HF, Freeman MW: Scavenger receptors class $\mathrm{A}-\mathrm{I} / \mathrm{II}$ and $\mathrm{CD} 36$ are the principal receptors responsible for the uptake of modified low density lipoprotein leading to lipid loading in macrophages. J Biol Chem 2002, 277: 49982-49988

36. Paglialunga S, Schrauwen P, Roy C, Moonen-Kornips E, Lu H, Hesselink MK, Deshaies Y, Richard D, Cianflone K: Reduced adipose tissue triglyceride synthesis and increased muscle fatty acid oxidation in C5L2 knockout mice. J Endocrinol 2007, 194:293-304

37. Li R, Coulthard LG, Wu MC, Taylor SM, Woodruff TM: C5L2: a controversial receptor of complement anaphylatoxin, C5a. FASEB J 2012, 27:855-864

38. Huber-Lang M, Sarma JV, Rittirsch D, Schreiber H, Weiss M, Flierl M, Younkin E, Schneider M, Suger-Wiedeck H, Gebhard F, McClintock SD, Neff T, Zetoune F, Bruckner U, Guo RF, Monk PN, Ward PA: Changes in the novel orphan, C5a receptor (C5L2), during experimental sepsis and sepsis in humans. J Immunol 2005, 174: $1104-1110$

39. Weber C, Noels H: Atherosclerosis: current pathogenesis and therapeutic options. Nat Med 2011, 17:1410-1422 